\title{
ЕКОНОМIЧНА ТЕОРIЯ
}

УДК 330.316.659

JEL classification M21

\author{
Зінченко О.А. \\ доктор економ. наук, професор \\ ORCID ID: 0000-0003-1156-1148 \\ Криворізький національний університет
}

Даріюш П.

канд. економ. наук

ORCID ID: 0000-0003-1328-7891

Польщча, мер м. Громадка

Зінченко Д.С.

ORCID ID: 0000-0001-8674-5449

Національний технічний університет Украӥни

«Київський політехнічний інститут ім. Ігоря Сікорського

\section{ІНФОРМАЦІЙНА ЕКОНОМІКА: КОНЦЕПЦІЯ, СУТНІСТЬ ТА РОЗВИТОК}

\section{THE INFORMATION ECONOMY: THE CONCEPT, THE ESSENCE AND THE DEVELOPMENT}

Визначено необхідність перегляду концептуальних підходів до визначення базових економічних понять, пов'язаних з впливом інформачії на економічні прочеси. Доведено, щзо всі прочеси, щуо протікають у сучасному світі мають абсолютну залежність від інформації, знань, інновацій, креативу $i$ в кінцевому підсумку базові засади формування конкурентоспроможності $i$ економічної безпеки на всіх рівнях господарювання сьогодні залежать від ефективності управління господарсько- економічними прочесами в контексті якості, повноти, своєчасності та ефективності використання необхідної інформації. У якості мети дослідження визначено вивчення сутності понять «інформаційне суспільство», «інформаційна економіка», удосконалення концепщії формування інформаційної економіки з перенесенням акцентів на необхідність формування вектору розвитку, орієнтованого на досягнення еклолгічності, інноваційності, інтелектуалізації та креативу та зростання якості життя. Доведено, щзо в сучасних умовах світової глобалізації та інформатизації існує необхідність перегляду базових канонів, пов'язаних з сприйняттям суспільством життєвих иінностей, орієнтованих на досягнення лише фінансово-економічних иілей (на перші щуабелі повинні виходити категорії, пов'язані з сочіалізацією, енверонікою, екологізацією, інноватизаџією, креативом та інформатизацією). Доведено, щзо в умовах формування інформачійної економіки важливим є збагачення інформаційного поля якісним креативно-інновачійним- наповненням, на основі якого за допомогою синергетичного ефекту створюватимуться якісно нові умови формування інформаџійного суспільства. I як наслідок 
- передумови для зростання якості життя людини. На основі аналізу підходів до визначення інформаційного суспільства визначено орієнтири на зростання його креативно- інноваційної складової. Наведене авторське бачення мети формування інформаційної економіки як оптимального використання інформаційних, інноваційних, інтелектуально-креативних ресурсів для створення передумов зростання якості життя населення через: а) гармонізацію та збалансованість суспільно-економічних відносин; б) покращення добробуту людей та соиіальної справедливості; в) підвищення екологічної, економічної та соиіальної безпеки.

Ключові слова: інформаційна економіка, інформаційне суспільство, концепція

The necessity to revise conceptual approaches to defining basic economic concepts related to the influence of information on economic processes is identified. It is proved that all the processes taking place in the modern world are absolutely dependent on information, knowledge, innovations, creativity and, ultimately, the basic principles of competitiveness and economic security at all levels of management today depend on the effectiveness of managing economic and economic processes in the context of quality, completeness, timeliness and efficiency of using the necessary information. The purpose of the study is to study the essence of the concepts of "information society", "information economy", improving the concept of forming an information economy with the shift of emphasis on the need to form a vector of development, focused on the achievement of ecological, innovative, intellectual and creative quality and growth. It is proved that in the current conditions of world globalization and informatization there is a need to revise the basic canons related to society's perception of vital values, oriented only to achieve financial and economic goals (the first steps should be the categories related to socialization, everonika, greening, innovation, creativity and informatization). It has been proved that in the conditions of formation of the information economy it is important to enrich the information field with a qualitative - creative and innovative filling, on the basis of which, by means of a synergistic effect, qualitatively new conditions of formation of the information society will be created. And as a consequence - prerequisites for increasing the quality of life. On the basis of the analysis of approaches to defining the information society, the guidelines for the growth of its creative and innovative component were determined. The author's vision of the purpose of information economy formation as an optimal use of information, innovative, intellectually-creative resources for creation of preconditions for increasing the quality of life of the population through: a) harmonization and balance of socio-economic relations; $b$ ) improving human well-being and social justice; c) enhancing environmental, economic and social security.

Key words: information economy, information society, concept

Вступ. Виходячи з викликів сучасного суспільства, настав час перегляду концептуальних підходів до визначення базових економічних понять, пов'язаних з впливом інформації на економічні процеси. Роль інформації в нинішніх глобалізаційних умовах неможливо переоцінити. Всі без виключення процеси, що протікають у сучасному світі мають абсолютну залежність від інформації, знань, інновацій, креативу. Ці поняття $\epsilon$ настільки тісно пов'язаними між собою, що вчені у своїх дослідженнях постійно використовують їх у симбіозі. I в кінцевому підсумку базові засади формування конкурентоспроможності і економічної безпеки на всіх рівнях господарювання сьогодні залежать від ефективності управління господарсько- економічними 
процесами в контексті якості, повноти, своєчасності та ефективності використання необхідної інформації.

В сучасних умовах світової глобалізації та інформатизації також існує необхідність перегляду базових канонів, пов'язаних з сприйняттям суспільством життєвих цінностей. Погляди світової спільноти, орієнтовані на досягнення лише фінансово-економічних цілей поступово відходять в минуле. На перші щабелі виходять категорії, пов'язані 3 соціалізацією, енверонікою, екологізацією, інноватизацією, креативом та інформатизацією.

Питання, пов'язані з предметом нашого дослідження, активно вивчаються науковцями та практиками, що належать до різних галузей науки.

Так, питання розумного розвитку людства в межах концепції енвіроніки $\epsilon$ предметом дослідження автора роботи [1]. Автор визначає новий квантовий етап розвитку суспільно- економічних відносин. У своїй роботі він стверджує, що розвиток продуктивних сил економік країн світу випереджає розвиток виробничих відносин. Наполягає на необхідності перегляду стратегій розвитку виробничих відносин на всіх рівнях - від світового рівня до рівня окремого господарюючого суб'єкта. Орієнтиром при цьому повинні, на думку автора роботи [1], виступати досягнення гармонійного збалансованого розвитку суспільно- економічних відносин. При цьому автор червоною ниткою підкреслює, що екологічність в широкому сенсі цього поняття виступає комплексним поняттям та враховує безліч суспільних процесів, у тому числі і інноваційно-інформаційно орієнтованих та базується на інформатизації всіх суспільних процесів.

Вищенаведені результати дослідженнь автора роботи [1] мають тісну кореляцію із загальносвітовими тенденціями концептуальних поглядів на розвиток економіки, на зміну іiі орієнтирів щодо досягнення економічної, екологічної, інформаційної, інноваційної збалансованості розвитку. Так, наприклад, підходи Організації об'єднаних націй ,згідно джерела «Evolution and the Green Economy in the Age of the Anthropocene» [2], мають трактування, близьке до вищенаведеної концепції, об'єднаної під лозунгом «The Green Economy» - зеленої економіки - економіки, що покликана «покращувати добробут людей і соціальну справедливість, в той же час значно знижуючи ризики для навколишнього середовища $\mathrm{i}$ екологічний дефіцит. $\mathrm{y}$ найпростішому вираженні зелена економіка є ресурсозберігаючою та соціально інклюзивною. Практично кажучи, зелена економіка - це та, в якій зростання доходів і зайнятості обумовлені державними і приватними інвестиціями, які скорочують забруднення навколишнього середовища» [2]. Вважаємо, що базовими засадами розробки будь-якої концепції розвитку суспільства та економіки повинні стати вищезгадані постулати.

Постановка завдання. Метою нашого дослідження є вивчення сутності понять «інформаційне суспільство», «інформаційна економіка», удосконалення 
концепції формування інформаційної економіки 3 перенесенням акцентів на необхідність формування вектору розвитку, орієнтованого на досягнення еклолгічності, інноваційності, інтелектуалізації та креативу та зростання якості життя.

Методологія. У якості методологічної бази використано системноцільовий підхід для визначення основних результатів дослідження та аналітичний метод для формування інформаційно-аналітичної бази роботи.

Результати дослідження. Розгляд концепції інформаційної економіки потребує більш детального висвітлення сутності поняття «інформаційне суспільство». Дефініції «інформаційне суспільство» і «інформаційна економіка» $\epsilon$ взаємопов'язаними та взаємозалежними. Формування інформаційної економіки не $\epsilon$ можливим за умов невідповідності суспільства критерію інформаційності.

Науковці приділяють дослідженню інформаційного суспільства багато уваги. Так, у роботі [3] визначається «Багато чого у цій виникаючій цивілізації протирічить традиційній індустріальній цивілізації. Це водночас і технічно розвинута, і антиіндустріальна цивілізація. "Третя хвиля" несе із собою новий образ життя, що оснований на джерелах енергії, які поповнюються; на методах виробництва, що роблять застарілими більшість фабричних збірничих ліній; на новому інституті, який можна було б назвати "електронним котеджем"; на радикально перетворених школах та корпораціях майбутнього. Така цивілізація несе 3 собою новий кодекс поведінки та виводить нас за межі концентрації енергії, грошових коштів і влади» [3]. У дослідженні [4] інформаційне суспільство визначається як «суспільство, де всі засоби інформаційної технології, тобто комп'ютери, інтегровані системи, кабельний, супутниковий та інший зв'язок, програмне забезпечення, наукові дослідження, націлені на те, щоб зробити інформацію загальнодоступною, що активно впроваджується у виробництво і життя» [4]. У роботі [5] визначається, що «специфіка образів інформаційного суспільства у свідомості українського суспільства полягає в недостатній ідеологічній, політичній визначеності місця інформаційної перспективи в розвитку країни. Ця перспектива на всіх рівнях суспільної свідомості та державних актах постає швидше, як технологічна, а не як цивілізаційна перспектива. Проблематика інформаційного суспільства стоїть осторонь політичних та ідеологічних розробок [5].

При цьому практично всі автори сходяться на думці, що ми живемо в епоху перетворення суспільства на інформаційне. I найважливішим питанням, що залежить наразі від нас, є збагачення інформаційного поля якісним креативно-інноваційним- наповненням, на основі якого за допомогою синергетичного ефекту створюватимуться якісно нові умови формування інформаційного суспільства. I як наслідок - передумови для зростання якості життя людини. 
Отже, нами на основі аналізу підходів до визначення інформаційного суспільства визначено орієнтири на зростання його креативно- інноваційної складової.

Своєчасність появи у вітчизняній економічній науці категорії «інформаційна економіка» $\epsilon$ аксіоматичною. Світова спільнота активно користується даною дефініцією вже не перший десяток років [6, 7, 8 та ін.]. Сьогодні абсолютно всі країни нашої планети в тому чи іншому ступені $\epsilon$ суб'єктами інформаційної економіки незалежно від того, визнають іiї існування чи ні. Глобалізаційні процеси наразі $\epsilon$ настільки багатовекторними, що наявність у них інформаційної складової не підлягає сумніву. Так, у Звіті про інформаційну економіку [9] на Конференції ООН з питань торгівлі та розвитку визначалось, що «інформаційна економіка $\epsilon$ одним із ключових понять у сучасній економіці. Розвиток концепції інформаційної економіки визнавав знання як товар, промислову діяльність, а потім вже- інформацію визнавав у якості технології [9].

Інформаційна економіка (the information economy), яка ще декілька років тому була лише науковим поняттям, плодом теоретичних здобутків дослідників-науковців, наразі дуже швидкими темпами перетворилась на об'єктивне загальносвітове явище.

Не дивлячись на неоднозначність трактування цього поняття вченими та практиками, ми не можемо не визнавати його існування.

Форми вираження такої характеристики економіки, як інформаційність, в різних країнах та регіонах $є$ різними, іноді кардинально відмінними та абсолютно неспівставними. Однак, в межах окремих країн, регіонів, культур в сучасних реаліях стає можливим надати певні сутнісні визначення поняття «інформаційна економіка» i, навіть, наблизитись до формулювання певних принципів, постулатів та механізмів, що супроводжують дане явище.

Ще 3 часів Ф.Махлупа, існування економіки знань, інформаційної економіки стало визнаним передовими умами людства. Так, Ф.Махлуп в роботі [6] при аналізі виробництва і розподілі знань в США виокремив такі групи діяльності, що складають сектор виробництва знань, як: освіта, наукові дослідження та розробки, засоби масової інформації, інформаційна техніка, інформаційні послуги; а також запропонував визначення інформаційної економіки як «такого типу економіки, де переважна частка валового внутрішнього продукту забезпечується діяльністю 3 виробництва, обробки, зберігання та передачі інформації i знань» [6]. 3 нашої точки зору це твердження є занадто категоричним з огляду на методи визначення того, що автор пропонує вважати знаннями. У загальноприйнятому сенсі Ф.Махлуп значну кількість обслуговуючого виробництва та інфраструктуру певним чином відносив до продукту знань, що є дещо дискусійним. 
Нам $є$ ближчим підхід до визначення інформаційної економіки, запропонований Д.Беллом у роботі [7]. При розгляді соціальних питань він презентував концепцію постіндустріального суспільства. В цій концепції також фігурували у якості ключових понять інформація та знання. На відміну від доробок Ф.Махлупа, в більш адаптованому до сучасних умов контексті: він поклав знання та інформацію в основу теорії вартості. Він стверджував, що систематизовані знання лежать в основі інновацій та формують нову вартість [7] .

Всі інші дослідження інформаційної економіки у другій половині минулого сторіччя тим чи іншим чином базувались на вищенаведених двох теоріях та всебічно (у тому числі статистично) доводили життєздатність цих теорій, розвиваючи та посилюючи їх.

Сучасний погляд економістів на поняття «інформаційна економіка» має певні специфічні риси, однак в основі вони класично мають домінування інформації, інновацій, знань, креативу, інтелектуального капіталу.

На думку автора роботи [8] інформаційна економіка $є$ «характеристикою сучасної економіки з погляду речового змісту, в якій відбувається поширення інформаційної технології у сфері матеріального і нематеріального виробництва, перетворення інформації на один із важливих факторів соціально-економічного прогресу» [8].

Згідно джерела [10] інформаційною визнається така економіка, в якій знання $є$ основним ресурсом i джерелом цінності. Основними піi характеристиками при цьому визначаються такі, як:

1) симбіоз та інтеграція технологій, у тому числі технологій зв'язку та обробки даних у комплексні інформаційні технології;

2) поширення впливу інформаційних технологій на економічну діяльність: збільшення долі інформаційних продуктів та персоналу, зайнятого на їх продукуванні;

3) збільшення застосування інформаційно-технологічних мереж в економічних інституціях.

Згідно Кембриджського англійського бізнес-словника [11], інформаційна економіка - це економіка, в якій знання, інформація та послуги є більш цінними, ніж виробництво (технологічна революція, пов'язана 3 комп'ютерною та інформаційною економікою, прискорила перехід індустріально розвинених країн від виробничої економіки до економіки, що базується на послугах - a саме-інформаційної економіки)» [11] .

Більшість вчених дебатують про принципи співіснування таких секторів економіки, сировиною та продуктами яких є матеріальний продукт або знання. Таким чином, виробничий сектор економіки (що базується на виробництві матеріального продукту) фактично протиставляють в такому сенсі базовим постулатам інформаційної економіки (інформаційний сектор, як зараз 
вважається базується на продукуванні лише інформаційного продукту, продукуванні знань).

Але, з нашої точки зору, такі жорсткі підходи до формування концепції інформаційної економіки, що виключають наявність виробничого сектору, $\epsilon$ перебільшенням. Загальновідомо, що без матеріального виробництва суспільство неспроможне існувати, а отже таке виробництво об'єктивно існуватиме завжди. Однак, підходи до формування всієї системи та інфраструктури матеріального виробництва 3 кожним роком будуть більш базуватись на інформації, на знаннях, залежати від них. Матеріальні блага необхідні людям у всіх їх видах без виключення. I лише за умови повного та ефективного задоволення вимог суспільства щодо кількості та якості матеріальних благ, згідно постулатів Маслоу, наступатиме етап виникнення і задоволення більш креативних потреб- потреб у знанні, інформації, креативі тощо.

Ми вважаємо, що формулювати концепцію світової інформаційної єкономіки та засади iї формування можна лише на засадах енвіроніки та зеленої єкономіки у їх симбіозі і сінергії. При цьому акцент у даних теоріях в аспекті нашого дослідження слід робити на важливості констатації такої мети: створення інформаційного суспільства, гармонійний збалансований розвиток суспільно-економічних відносин, покращення добробуту людей, соціальної справедливості та екологічної безпеки (рис.1).

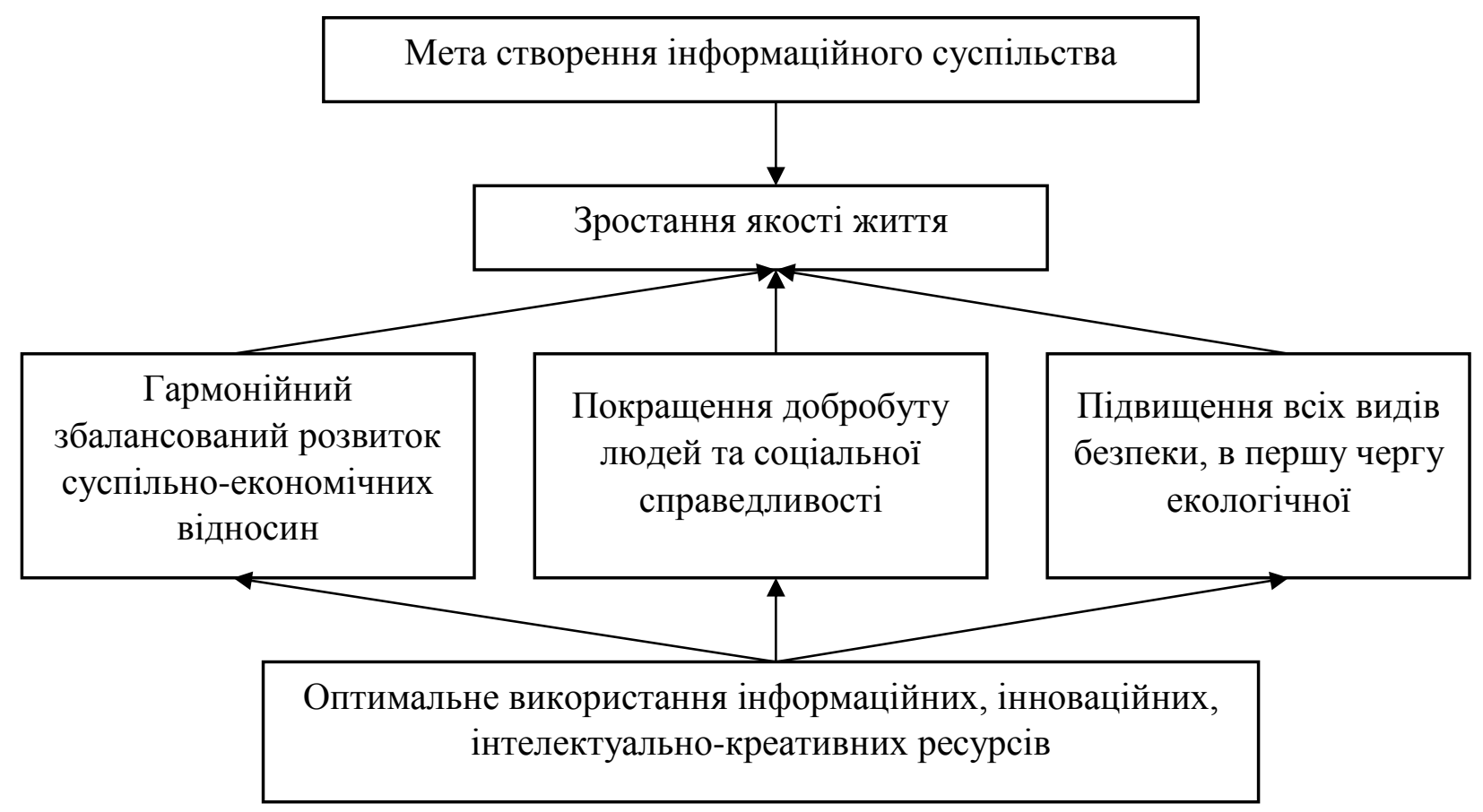

Рисунок 1 - Мета створення інформаційного суспільства 
Такі чинники окреслені нами для визначення мети формування інформаційного суспільства тому, що в сучасних турбулентних умовах стрімкість розвитку всіх процесів у світі є просто непередбачуваною і розвиток інформаційного суспільства, інформаційної економіки значно підвищує таку швидкість. I від того, який вектор розвитку екології, економіки, соціуму оберемо, залежить не просто добробут людства, а сама можливість його існування. Існування цивілізації в цілому залежить від напряму розвитку, яке світове суспільство обере сьогодні. Тому вкрай важливо за допомогою всього необмеженого інструментарію інформаційного суспільства формувати саме такі засади, які б дозволили підвищити якість життя.

Мета ж формування інформаційної економіки базується на постулатах, визначених у меті створення інформаційного суспільства 3 акцентами на економічних чинниках (рис. 2).

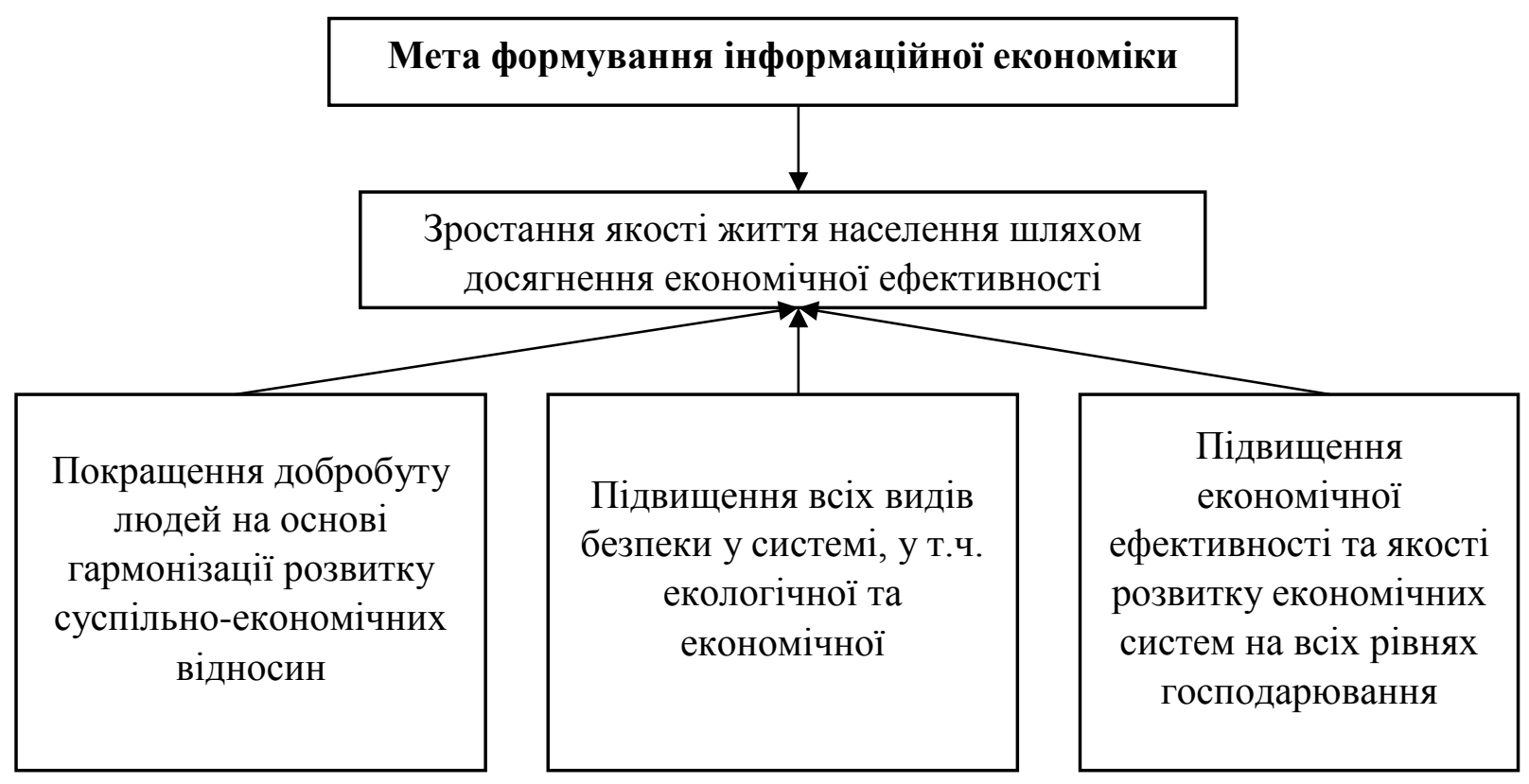

Рисунок 2 - Мета формування інформаційної економіки

Базовим, ключовим чинником, що відрізняє концепцію інформаційної економіки від концепції інформаційного суспільства $\epsilon$ цілеполягання на отримання економічного результату. Таким результатом на рівні підприємств $\epsilon$ збільшення економічної ефективності, зростання ринкової вартості підприємства, позитивна капіталізація за умов збереження економічної безпеки підприємства.

Отже, підсумовуючи наведене вище, можна запропонувати наступне авторське бачення щодо визначення мети формування інформаційної економіки (з огляду на первинність енвіроніки та «зеленої економіки»). 
Метою формування інформаційної економіки є оптимальне використання інформаційних, інноваційних, інтелектуально-креативних ресурсів для створення передумов зростання якості життя населення через: а) гармонізацію та збалансованість суспільно-економічних відносин; б) покращення добробуту людей та соціальної справедливості; в) підвищення екологічної, економічної та соціальної безпеки.

Наш погляд на концепцію інформаційної економіки охоплює такі іiі складові (рис.3).

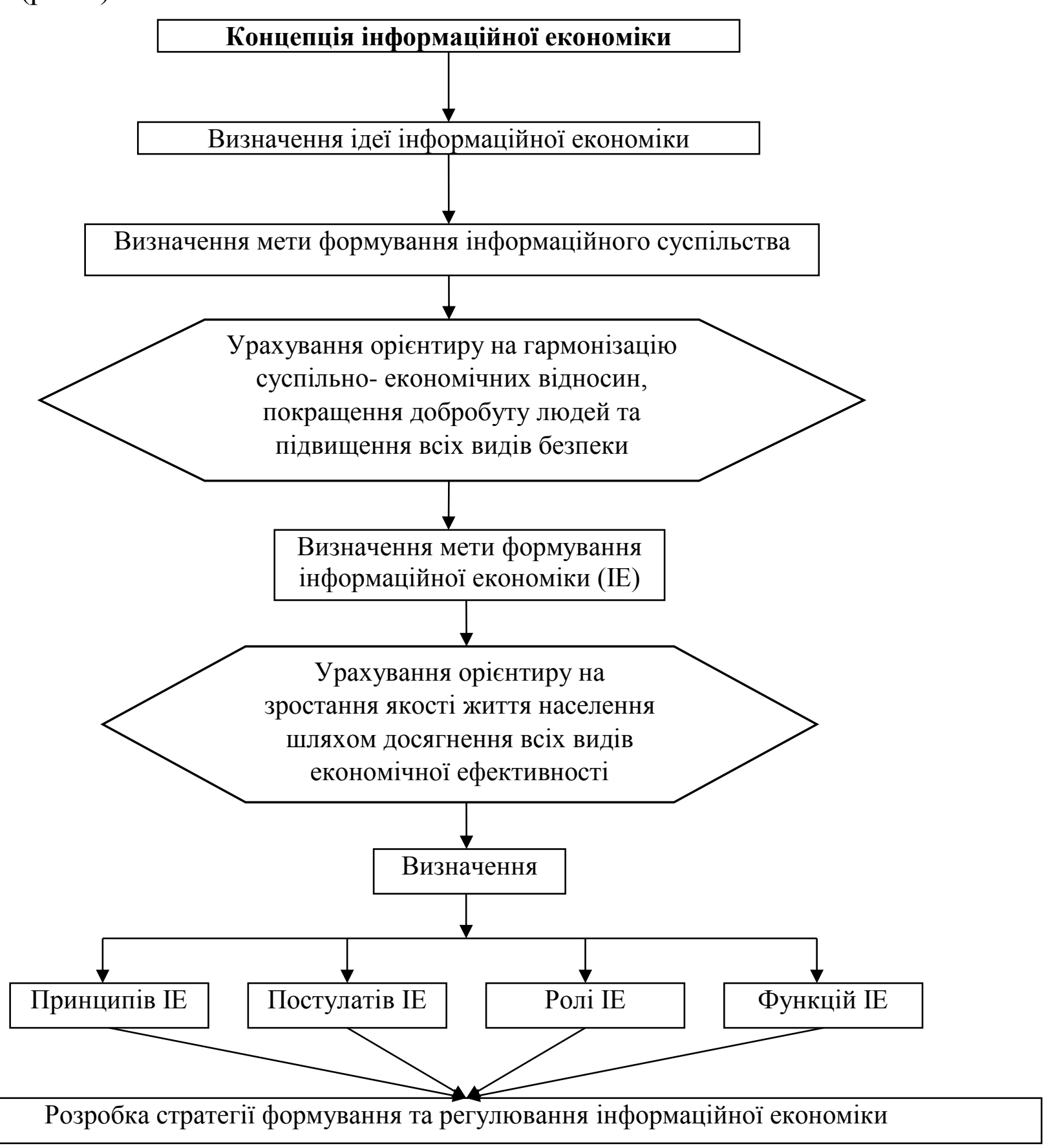

Рисунок 3 - Схема розробки концепції формування інформаційної економіки 
Яскравим прикладом вдалого поєднання цифрових технологій 3 обслуговуванням діяльності підприємств та населення для підвищення зручності користувачів є впроваджена 22 травня 2019 система «Трембіта». Це система автоматичного обміну даними між державними органами без участі людей. Підвищена швидкість всіх операцій. Виключена корупційна складова. Значно зменшені витрати бюджетних коштів на проведення всіх операцій.

За даними Державного агентства 3 питань електронного урядування України [12] на даний час розробляється значна кількість проектів, пов'язаних 3 діджиталізацією значної кількості господарських процесів на підприємствах.

Наприклад, такі, як розширення переліку електронних послуг, об`єднання державних реєстрів в єдину систему взаємодії - ефективний спосіб оптимізації роботи державних органів, боротьби 3 бюрократією, забезпечення дистанційного та оперативного доступу громадян до якісних адміністративних послуг, досягнення інтероперабельності - принципу, коли різні інформаційні ресурси можуть взаємодіяти між собою на базі уніфікованих інтерфейсів та протоколів [12].

Важливим для активізації формування інформаційної економіки, з нашої точки зору, є також формування публічних електронних реєстрів, відкритість даних та розширення електронного документообігу, що впроваджуються Державним агентством 3 питань електронного урядування України за багатьма напрямками.

Висновки. На основі аналізу підходів дослідників до визначення понять «інформаційне суспільство», «інформаційна економіка», запропоновано авторський погляд на удосконалене визначення сутності інформаційної економіки з ціле поляганням на зростання якості життя населення шляхом зростання економічної ефективності на основі оптимального використання інформаційних, інтелектуальних, креативних, інноваційних ресурсів. На цій основі запропоновано удосконалені концепції формування інформаційного суспільства та інформаційної економіки. Перспективами наукових досліджень у даному напрямку $є$ доведення теоретико-методологічних положень до рівня конкретних методик та практичних рекомендацій.

\section{Література:}

1.Белопольский Н.Г. Энвироника - наука будущего развития человечества / Н.Г. Белопольский. - 3-е изд., перераб. и доп. / Донецк: НАН Украины. Ин-т экономики пром-сти, 2007. - 436с.

2. Evolution and the Green Economy in the Age of the Anthropocene

[Електронний pecypc] - Режим доступу:https://www.unenvironment.org/news-andstories/news/evolution-and-green-economy-age-anthropocene

3. Тоффлер О. Третья волна . США - экономика, политика, идеология./ О. Тоффлер. 1982.№3. 
4. Ракитов А.И. Информация, наука, технология в глобальных исторических изменениях / А.И. Ракитов. - М.: Прогресс, 1998. - 104 с.

5. Рубанець О.М. Інформаційне суспільство: когнітивний креатин постнекласичних досліджень: Монографія. / О.М. Рубанець. - К.: ПАРАПАН, 2006. - 420 с.

6. Махлуп Ф. Производство и распространение знаний в США (.: Fritz Machlup. The Production and Distribution of Knowledge in the United States) / Фриц Махлуп. - - Москва : Прогресс, 1966. - 462 с.;

7. Белл Д. Грядущее постиндустриальное общество. Опыт социального прогнозирования. M.: Academia, 2004, C. CLII

8 Економічна енциклопедія. Т1./ Редкол...: С.В.Мочерний та ін.. - К.:Видавничий центр «Академія», 2000. - 864c.

9.Information Economy Report (Series) // United nations conference on trade and development [Електроннй ресурс] - Режим доступу: https://unctad.org/en/Pages/Publications/InformationEconomyReportSeries.aspx

10. The information economy [Електронний ресурс]- Режим доступу:www.businessdictionary.com

11. [ Cambridge Business English Dictionary (C) Cambridge University Press) [Електронний pecypc] - Режим доступу: https://dictionary.cambridge.org

12. Головна сторінка Державного агентства 3 питань електронного урядування України [Електронний ресурс] - Режим доступу:https://www.e.gov.ua/ua

УДК 338.001 .36

JEL classification: $B 59$

Крейдич I.М. доктор економ. наук, професор ORCID ID:0000-0002-4594-2160

Рощина Н.В. канд. економ. наук, дочент ORCID ID: 0000-0003-2035-8846

Канцедал Г.О. ORCID ID: 0000-0003-2740-2176

Національний технічний університет України «Київський політехнічний інститут імені Ігоря Сікорського»

\section{КОНЦЕПЦІЯ ЕФЕКТУАЦІЇ В УМОВАХ ФУНДАМЕНТАЛЬНОЇ НЕВИЗНАЧЕНОСТІ}

\section{THE CONCEPT OF EFFECTUATION IN CONDITIONS OF FUNDAMENTAL UNCERTAINTY}

У статті розглядається концепція ефектуації в умовах фундаментальної невизначеності. Доведено, щзо зазначені умови характеризуються невпорядкованістю руху, ірраціональною поведінкою суб'єктів економічних відносин, можливістю різних траєкторій 